\title{
The Eight Stages of Psychosocial Protective Development: Developmental Psychology
}

\author{
Dingyu Chung \\ Utica, Michigan, USA \\ Email: dy_chung@yahoo.com
}

How to cite this paper: Chung, D.Y. (2018) The Eight Stages of Psychosocial Protective Development: Developmental Psychology. Journal of Behavioral and Brain Science, 8, 369-398.

https://doi.org/10.4236/jbbs.2018.86024

Received: April 25, 2018

Accepted: June 9, 2018

Published: June 12, 2018

Copyright $\odot 2018$ by author and Scientific Research Publishing Inc. This work is licensed under the Creative Commons Attribution International License (CC BY 4.0).

http://creativecommons.org/licenses/by/4.0/

\begin{abstract}
The proposed universal psychological mechanism for developmental psychology is the mental protective system whose different parts emerge and mature in the eight different stages of psychosocial protective development under different social interactions. The proposed eight stages of psychosocial protective development are childhood (infancy, toddlerhood, pre-juvenile age, and juvenile age), adolescence, early young adulthood, late young adulthood, early middle adulthood, late middle adulthood, early late adulthood, and late late adulthood. The mental protection system consists of four socialities (collectivistic, individualistic, interdependent, and generativity), three worldviews (territorial, competitive, and cooperative), and the mental immune system for four regulated and unregulated countermeasures (hyperactivity, phobia, comforter, and rationality) against adversities. During childhood, dependent children have collectivistic sociality under the protection of committed parents and territorial worldview with the boundary of family. Children start with the unregulated mental immune system without delayed gratification due to mental immaturity, and gradually acquire the regulated mental immune system with delayed gratification through mental maturity. Adolescents transit to adulthood. Independent adults have the regulated metal immune system, individualistic sociality with reciprocity, and competitive-cooperative worldviews without boundary. After the age of 50, older people as elder leaders-mentors develop generativity sociality to protect next generation. The paper shows that the mental protective system as the universal psychological mechanism for developmental psychology explains clearly psychosocial protective development, the human evolution, the Piaget's cognitive development, the Erikson's psychosocial (ego-social) development, the Confucius' (educated person's) six milestones of life, and parent-child relation in the Abrahamic religions (Judaism, Christianity, and Islam) and Confucianism.
\end{abstract}

\section{Keywords}

Developmental Psychology, Mental Protection System, Universal Psychological 
Mechanism, Psychosocial Protective Development, Developmental Stages, Brain, Human Evolution, Jean Piaget. Erik Erikson, Confucius, Abrahamic Religions, Confucianism

\section{Introduction}

In developmental psychology [1] to explain growth and change through the lifespan, the developmental stages of life are initiated by distinct transitions in physical, cognitive, and socioemotional developments. Different theories of developmental psychology have different stages of development. For examples, the Jean Piaget's four stages of cognitive development are sensorimotor stage, pre-operational stage, concrete operational stage, and formal operational stage [2]. The Erik Erikson's eight stages of psychosocial (ego-social) development are infancy, toddlerhood, preschooler, schooler, adolescence, young adulthood, middle adulthood, and late adulthood [3]. Confucius said: "At fifteen my heart was set on learning; at thirty I stood firm; at forty I had no more doubts; at fifty I knew the mandate of Heaven; at sixty my ear was obedient; at seventy, I could follow my heart's desire without transgressing the norm." (Analects 2:4) The Confucius' six milestones of life correspond to the six milestones of an educated person.

The Piaget's cognitive development, the Erikson's psychosocial development, and the Confucius' six milestones of life are descriptive overviews of human cognitive, ego-social, and educational developments, but they do not have a universal psychological mechanism for the developments. As a result, they cannot explain adequately how or why these developments occur [4]. The objective of the paper is to establish such universal psychological mechanism for developmental psychology. In this paper, the proposed universal psychological mechanism for the developmental stages of life is the mental protective system [5] whose different parts emerge and mature in different stages under different social interactions. This development is the psychosocial protective development to combine the mental protective system and social interactions.

As described in the previous paper [5], the mental protection system of body consists of the social brain to set up the protective social groups for vulnerable social members-functions and the mental immune system to produce the mental protective countermeasures against adversities, corresponding to the physical protection system of the body consisting of the integumentary system to set up the protective organs for vulnerable body parts-functions and the immune system to produce the protective countermeasures against harmful invaders (pathogens). The social brain includes sociality and worldview. The four parts in sociality are collectivistic sociality to protect children, individualistic sociality to protect individuals, interdependent sociality to protect pregnant females, and generativity sociality to protect next generation. The three parts in worldview are 
territorial worldview to protect territory, competitive worldview to protect competition, and cooperative worldview to protect cooperation. The mental immune system produces unregulated and regulated countermeasures against adversities. A regulated countermeasure contains a regulator to constrain countermeasure. The countermeasures against adversities include hyperactivity against danger, phobia against unfamiliarity-uncertainty, comforter against hardship, and rationality against unfamiliarity-uncertainty.

The proposed eight stages of psychosocial protective development are childhood (infancy, toddlerhood, pre-juvenile age, and juvenile age), adolescence, early young adulthood, late young adulthood, early middle adulthood, late middle adulthood, early late adulthood, and late late adulthood. At the different stages, different parts in the mental protective system in the brain appear and mature under different social interactions. The formation of the eight stages is derived from the human evolution, and explains the Piaget's cognitive development, the Erikson's psychosocial development, and the Confucius' six milestones of life.

A most important relation in the psychosocial protective development is parent-child relation. Such parent-child relation changes with the changes of developmental stages. Parent-child relation is important in the Abrahamic religions (Judaism, Christianity, and Islam) and Confucianism. This paper compares the Abrahamic religions and Confucianism in terms of parent-child relation. The conclusion of the paper is that the mental protective system is the universal psychological mechanism for developmental psychology to explain clearly psychosocial protective development, the human evolution, the Piaget's cognitive development, the Erikson's psychosocial (ego-social) development, the Confucius' (educated person's) six milestones of life, and parent-child relation in the Abrahamic religions and Confucianism. Section 2 discusses the mental protective system and the eight stages of psychosocial protective development. Section 3 describes childhood. Section 4 describes adolescence and adulthood. Section 5 discusses parent-child relation in the Abrahamic religions and Confucianism.

\section{The Formation of the Eight Stages of Psychosocial Protective Development}

The proposed universal psychological mechanism for developmental psychology is the mental protective system whose different parts emerge and mature in the eight different stages of psychosocial protective development under different social interactions. As described in the previous paper [5], the mental protection system consists of the four socialities to protect vulnerable social members, the three worldviews to protect vulnerable social functions, and the mental immune system for the four countermeasures against adversities. The mental protection system is described in Table 1.

The four socialities to protect social members are collectivistic sociality from 
Table 1. The mental protective system.

\begin{tabular}{|c|c|}
\hline Mental protective system & Parts \\
\hline \multirow{4}{*}{ Socialities to protect social members } & 1) collectivistic sociality from kin-friends to protect children through commitment \\
\hline & 2) individualistic sociality from allies to protect individuals through reciprocity \\
\hline & $\begin{array}{l}\text { 3) interdependent sociality from specialists to protect pregnant females through interdependent division } \\
\text { of labor }\end{array}$ \\
\hline & 4) generativity sociality from older leaders-mentors to protect next generation through reciprocity \\
\hline \multirow{3}{*}{ Worldviews to protect social functions } & 1) territorial worldview to protect territory through ingroup-outgroup \\
\hline & 2) competitive worldview to protect competition through outgroup-like group \\
\hline & 3) cooperative worldview to protect cooperation through ingroup-like group \\
\hline \multirow{4}{*}{$\begin{array}{l}\text { Mental immune system for } \\
\text { countermeasures against adversities }\end{array}$} & 1) unregulated or regulated hyperactivity countermeasure against danger to maintain existence \\
\hline & 2) unregulated or regulated phobia countermeasure against unfamiliarity-uncertainty to maintain tradition \\
\hline & 3) unregulated or regulated comforter countermeasure against hardship to maintain durability \\
\hline & $\begin{array}{l}\text { 4) unregulated or regulated rationality countermeasure against unfamiliarity-uncertainty to maintain } \\
\text { adaptability }\end{array}$ \\
\hline
\end{tabular}

kin-friends to protect vulnerable children through commitment, individualistic sociality from allies to protect vulnerable individuals through reciprocity, interdependent sociality from interdependent specialists to protect vulnerable pregnant females through interdependent division of labor, and generativity sociality from older leaders-mentors to protect next generation through reciprocity. Children live in collectivistic sociality under the protection of committed parents. Adults live in individualistic sociality under reciprocal relations among reciprocal adult allies. Interdependent sociality exists only in few social animals, and generativity sociality exists only in human. Interdependent sociality protects vulnerable pregnant females against neglect by forming interdependent specialists for the division of labor. For example, bees have the vulnerable pregnant queen bee whose specialty is reproduction and who requires the care of infertile female worker bees as procurement specialists that require the queen bee to reproduce. As a result, bees form the interdependent specialists consisting of reproductive queen bees, infertile female worker bees, and fertile male drones. Interdependent sociality is eusociality [6] as the highest level of organization of animal sociality. Ants, bees, and termites are eusocial animals. Human is a species of eusocial ape [7]. As described in the previous paper [8], bipedalism started the evolution of early human ancestors, but the primitive feet from the original bipedalism were still suitable for climbing trees, and not suitable to run fast on the ground especially for pregnant women and small children. Pregnant females were vulnerable on the ground without protection. As a result, the interdependent specialists for the division of labor were evolved to protect vulnerable pregnant females. During human evolution, the interdependent specialists of the hunter-gatherer society consisted of fertile homemaker-gatherer, fertile explorer-hunter, and infertile leader-mentor [8]. Such interdependent specialists 
produced theory of mind (mind-reading) that recognizes that the other specialists exist to think for themselves. Theory of mind allows specialists to appreciate, utilize, and coordinate with one another [9]. Interdependent sociality with explicit theory of mind starts at about the age of four.

Used in the psychology of Erik Erikson [3], generativity that exists only in humans involves the care and concern from older people to establish and guide next generation [10] as the legacy to the whole society [11]. In the monogamous hunter-gatherer society during human evolution, individuals (monogamous couples) after menopause became infertile. Such infertile individuals at the age of menopause were likely to be leaders-mentors with abundant knowledge, experiences, and social connections, even though physically they were weaker than young adults. After menopause, these infertile leaders-mentors could not have dependent children, so without dependent children, the infertile leaders-mentors were generous in protecting next generation instead of protecting their own dependent children. At the same time, without the physical strength of young adults, infertile leaders-mentors needed the physical protection from strong young adults who did not have comparable generosity in the protection of next generation as well as comparable knowledge, experiences, and social connections as infertile leaders-mentors. As a result, in the human division of labor for interdependent sociality, infertile leader-mentor became an interdependent specialist. The generous, knowledgeable, experienced, and well-connected infertile leader-mentor specialists provided a significant evolutionary competitive advantage in the human evolution, resulting in long life after menopause unlike other great apes that have short life after menopause. Increased longevity through generativity was proved by the computer simulation of increased longevity through grandmothering [12]. During the human evolution, some unique variants, such as ApoE3, in genes were evolved to lower the the risk of most aging diseases [13].

The three worldviews to protect social functions are territorial worldview with boundary to protect territory through the division of ingroup and outgroup, competitive worldview without boundary to protect competition function, cooperative worldview without boundary to protect cooperation function. Dependent children during childhood live basically in a protected environment of family with the clear boundary between ingroup and outgroup, so children have territorial worldview. Adults during adulthood live in an open environment without clear boundary, so adults have competitive-connective worldviews. Adolescents transit to competitive-cooperative worldviews.

The mental immune system produces four countermeasures against adversities. An unregulated countermeasure contains no regulator to constrain countermeasure, while a regulated countermeasure contains a regulator to constrain countermeasure. The extreme unregulated countermeasures result in personality-mental disorders as mental allergies and mental autoimmune diseases like physical allergies and autoimmune diseases without regulators [5]. A symptom of perso- 
nality-mental disorders as mental allergies and mental autoimmune diseases is the overactive countermeasure against ubiquitous perceived adversity. The countermeasures against adversities include hyperactivity against danger to maintain existence, phobia against unfamiliarity-uncertainty to maintain tradition, comforter against hardship to maintain durability, and rationality against unfamiliarity-uncertainty to maintain adaptability. Children start with the unregulated mental immune system due to mental immaturity, and gradually acquire the regulated mental immune system with mental maturity.

The proposed eight stages of psychosocial protective system based on the mental protective system and social system for the maturation process are childhood (from birth to 12 -year old), adolescence (12 - 18), early young adulthood (18 - 25), late young adulthood (25 - 40), early middle adulthood (40 - 50), late middle adulthood (50 - 70), early late adulthood (70 - 85), and late late adulthood $(85+)$, while the four periods in childhood are infancy (from birth to 1.5-year old), toddlerhood (1.5 - 3), pre-juvenile age (3 - 6), and juvenile age (6 12) as shown in Figure 1. Different parts in the mental protective system in the brain appear and mature in different stages of the development as shown in Table 2.

Different theories of developmental psychology have different stages of development. For examples, The Jean Piaget's four stages of cognitive development are sensorimotor stage, pre-operational stage, concrete operational stage, and formal operational stage [2] as in Table 3. A child must master each stage before moving to the next stage in a continuous learning process where each stage builds on the previous one.

The Erik Erikson's eight stages of psychosocial development are infancy, toddlerhood, preschooler, schooler, adolescence, young adulthood, middle adulthood, and late adulthood [3] as in Table 4. According to the Erikson's psychosocial development, the ego develops through eight stages, each characterized by a basic psychosocial crisis, such as trust versus distrust and intimacy versus isolation. The acquisition of basic virtues, such as hope and love, results from successful completion of each stage. Basic virtues can be used by the ego to resolve subsequent crises.

The paper shows that the mental protective system as the universal psychological mechanism for developmental psychology explains clearly psychosocial protective development, the human evolution, the Piaget's cognitive development,

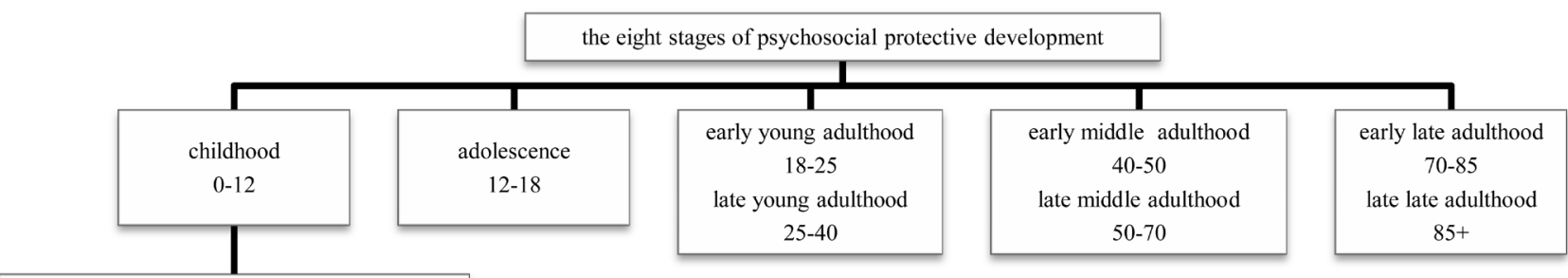

infancy (0-1.5), toddlerhood (1.5-3), pre-juvenile age (3-6), juvenile age (6-12)

Figure 1. The eight stages of psychosocial protective development. 
Table 2. The eight stages of psychosocial protective development.

\begin{tabular}{|c|c|c|c|c|c|c|c|c|}
\hline mental protective parts/ages & $0-12$ & $12-18$ & $18-25$ & $25-40$ & $40-50$ & $50-70$ & $70-85$ & $85+$ \\
\hline & $\begin{array}{l}\text { childhood } \\
\text { (age period) }\end{array}$ & adolescence & $\begin{array}{c}\text { Early } \\
\text { young } \\
\text { adulthood }\end{array}$ & $\begin{array}{c}\text { late } \\
\text { young } \\
\text { adulthood }\end{array}$ & $\begin{array}{c}\text { early } \\
\text { middle } \\
\text { adulthood }\end{array}$ & $\begin{array}{c}\text { late } \\
\text { middle } \\
\text { adulthood }\end{array}$ & $\begin{array}{c}\text { early } \\
\text { late } \\
\text { adulthood }\end{array}$ & $\begin{array}{c}\text { late } \\
\text { late } \\
\text { adulthood }\end{array}$ \\
\hline collectivistic sociality & $\checkmark(0-12)$ & transition & $\checkmark$ & $\checkmark$ & $\checkmark$ & $\checkmark$ & $\checkmark$ & $\checkmark$ \\
\hline interdependent sociality & $\checkmark(4-12)$ & $\checkmark$ & $\checkmark$ & $\checkmark$ & $\checkmark$ & $\checkmark$ & $\checkmark$ & $\checkmark$ \\
\hline individualistic sociality & & & $\checkmark$ & $\checkmark$ & $\checkmark$ & $\checkmark$ & $\checkmark$ & $\checkmark$ \\
\hline territorial worldview & $\checkmark(0-12)$ & transition & $\checkmark$ & $\checkmark$ & $\checkmark$ & $\checkmark$ & $\checkmark$ & $\checkmark$ \\
\hline competitive worldview & & & $\checkmark$ & $\checkmark$ & $\checkmark$ & $\checkmark$ & $\checkmark$ & $\checkmark$ \\
\hline cooperative worldview & & & $\checkmark$ & $\checkmark$ & $\checkmark$ & $\checkmark$ & $\checkmark$ & $\checkmark$ \\
\hline generativity sociality & & & & & & $\checkmark$ active & $\checkmark$ advisory & $\checkmark$ wise \\
\hline unregulated hyperactivity & $\checkmark(0-1.5)$ & & & & & & & \\
\hline regulated hyperactivity & $\checkmark(1.5-12)$ & $\checkmark$ & $\checkmark$ & $\checkmark$ & $\checkmark$ & $\checkmark$ & $\checkmark$ & $\checkmark$ \\
\hline unregulated phobia & $\checkmark(0-1.5)$ & & & & & & & \\
\hline regulated phobia & $\checkmark(1.5-12)$ & $\checkmark$ & $\checkmark$ & $\checkmark$ & $\checkmark$ & $\checkmark$ & $\checkmark$ & $\checkmark$ \\
\hline unregulated comforter & $\checkmark(3-6)$ & & & & & & & \\
\hline regulated comforter & $\checkmark(6-12)$ & $\checkmark$ & $\checkmark$ & $\checkmark$ & $\checkmark$ & $\checkmark$ & $\checkmark$ & $\checkmark$ \\
\hline unregulated rationality & & $\checkmark$ & $\checkmark$ & & & & & \\
\hline regulated rationality & & & & $\checkmark$ & $\checkmark$ & $\checkmark$ & $\checkmark$ & $\checkmark$ \\
\hline
\end{tabular}

Table 3. The Piaget's cognitive development.

\begin{tabular}{|c|c|c|c|}
\hline age & stage & understands world through & learned cognitive capabilities \\
\hline $0-2$ & sensorimotor & senses and actions & $\begin{array}{l}\text { coordination of senses with motor responses and language used for demands } \\
\text { and cataloguing }\end{array}$ \\
\hline $2-7$ & preoperational & mental images and language & $\begin{array}{l}\text { symbolic thinking and language with proper syntax and grammar to express } \\
\text { full concepts }\end{array}$ \\
\hline $7-11$ & $\begin{array}{c}\text { concrete } \\
\text { operational }\end{array}$ & concrete rational thinking and categories & concepts attached to concrete situations \\
\hline $11+$ & $\begin{array}{c}\text { formal } \\
\text { operational }\end{array}$ & $\begin{array}{l}\text { abstract rational thinking and scientific } \\
\text { reasoning }\end{array}$ & $\begin{array}{l}\text { theoretical, hypothetical, and counterfactual thinking, abstract logical } \\
\text { reasoning }\end{array}$ \\
\hline
\end{tabular}

Table 4. The Erikson's psychosocial (ego-social) development.

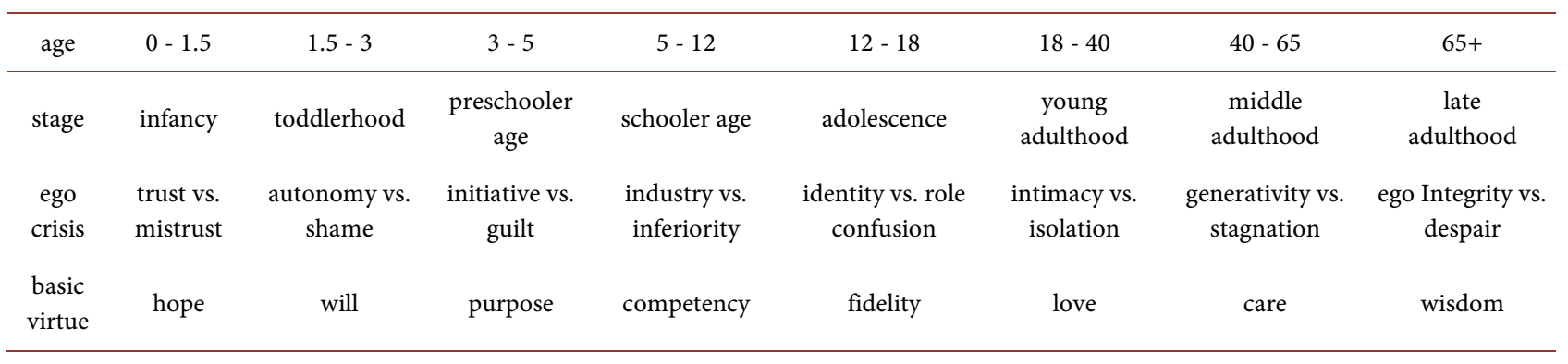


the Erikson's psychosocial (ego-social) development, the Confucius' (educated person's) six milestones of life, and parent-child relation in the Abrahamic religions (Judaism, Christianity, and Islam) and Confucianism as shown in Figure 2 .

\section{Childhood}

The proposed psychosocial protective development explains the Piaget's cognitive development and the Erikson's psychosocial development. The four periods in childhood are infancy, toddlerhood, pre-juvenile age, and juvenile age, and are derived from the human evolution. The Jean Piaget's three stages of cognitive development for childhood are sensorimotor stage, pre-operational stage, and concrete operational stage. The Erikson's four stages of psychosocial development for childhood are infancy, toddlerhood, preschooler age (pre-juvenile age), and schooler age (juvenile age). These four periods in childhood are described in Table 5.

All the four periods in childhood are under collectivistic sociality with the protection of committed parents and under territorial worldview with protective

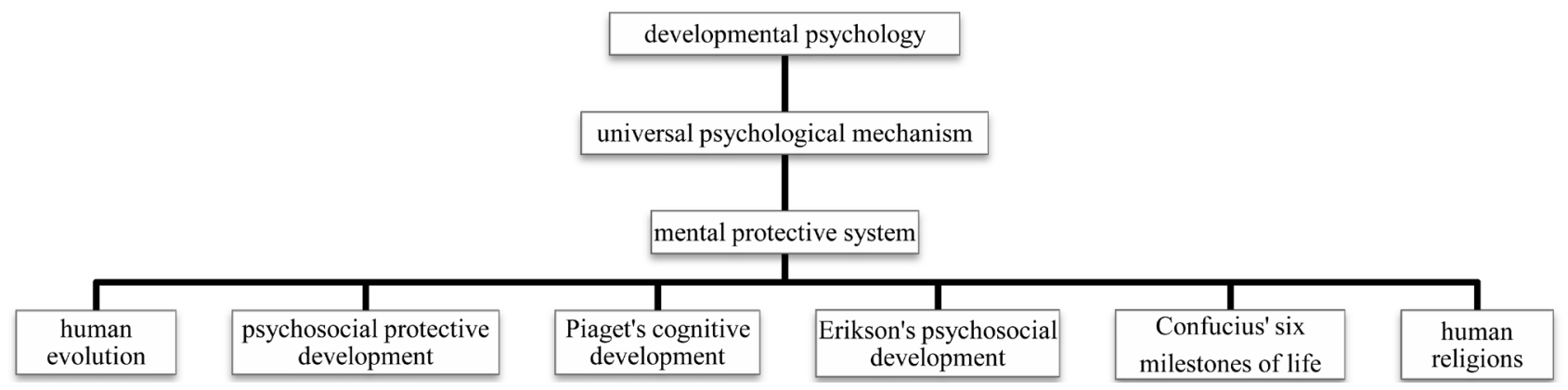

Figure 2. The mental protective system as the universal psychological system for developmental psychology.

Table 5. Childhood.

\begin{tabular}{|c|c|c|c|c|}
\hline age & $0-1.5$ & $1.5-3$ & $3-6$ & $6-12$ \\
\hline period & infancy & toddlerhood & $\begin{array}{l}\text { pre-juvenile age } \\
\text { (preschooler age) }\end{array}$ & $\begin{array}{l}\text { juvenile age } \\
\text { (schooler age) }\end{array}$ \\
\hline start at & birth & walking & weaning & adult-type teeth \\
\hline major activity & to survive & to explore & to initiate & to accomplish \\
\hline sociality & collectivistic & collectivistic & $\begin{array}{c}\text { collectivistic } \\
\text { interdependence }\end{array}$ & $\begin{array}{c}\text { collectivistic } \\
\text { interdependence }\end{array}$ \\
\hline worldview & territorial & territorial & territorial & territorial \\
\hline hyperactivity & unregulated & regulated & regulated & regulated \\
\hline phobia & unregulated & regulated & regulated & regulated \\
\hline Erikson's virtue & hope to survive in ingroup & will to live in ingroup & purpose to live in ingroup & competence to live in ingroup \\
\hline \multirow{2}{*}{ Piaget's stage } & $0-2$ & $2-7$ & & $7-11$ \\
\hline & sensorimotor & preoperational & & concrete operational \\
\hline
\end{tabular}


boundary of family. The most important relation during childhood is the parentchild relation. The mental immune system of dependent child relies on committed parents. To dependent child under collectivistic sociality, committed parents are the protector against danger, the authority against unfamiliarity-uncertainty, and the love against hardship. The insufficient care of parents damages the child mental immune system, resulting in personality-mental disorders. However, the brain has the capacity to change in terms of plasticity. A child who had insufficient care can often become cheerful and affectionate with sufficient care [14]. Child is highly dependent on parent, so child has a highly restricted free-will.

\subsection{Infancy (From Birth to 1.5 Year Old)}

- Infancy starts at birth, and the major activity is to survive.

- Collectivistic sociality and territorial worldview

- Unregulated hyperactivity against danger and unregulated phobia against unfamiliarity-uncertainty

- Committed parents are the protector against danger and the authority against unfamiliarity-uncertainty

- The Erikson's virtue is the hope to survive in ingroup

Infancy starts at birth, and the major activity is to survive. Important persons are parents or primary caregivers. To walk well, human bipedalism limits the size of the pelvis, resulting in the narrow birth canal. Human brains become too big to pass through the birth canal when fully developed. A human newborn averages $369 \mathrm{ml}$, and increases, during the first year of life, to about $961 \mathrm{ml}$, after which the growth rate declines. Brain volume peaks at the age of 40 after which it begins declining at 5\% per decade, speeding up around 70 [15]. Adult Homo sapiens have brains averaging $1200 \mathrm{ml}$ or more. Consequently, human infants are highly immature, unlike other great apes that have precocial newborns with the relatively mature brains. A newborn's brain has a well-developed brainstem and midbrain to carry out the bodily functions necessary for life, but the sections of the brain that are involved in regulating emotions and motions and learning language grow and develop after birth, so human newborns remain physically altricial for a very long time.

Due to the highly immature brain at birth, the mental immune system is unregulated with unregulated hyperactivity against danger and unregulated phobia against unfamiliarity-uncertainty. For infants, all needs have to be met at once, and there is no delayed gratification. The way to express the countermeasures (hyperactivity and phobia) is relentless cry, the most powerful survival adaptation for infants. A human infant is born within a group of caring parents and relatives who inevitably response to baby's relentless cry. The infant mental immune system relies on committed parents.

Infants have territorial worldview with the family boundary between ingroup and outgroup. Infants basically live in ingroup where individuals have similar interests and outlooks, and produce the feeling of cooperation among people in 
ingroup [16]. The worldview for infants is territorial worldview against people in outgroup with the feeling of zero-sum competition. As shown in the Infant Cognition Center at Yale University, infants at few months old [17] prefer the objects (such as dolls) as ingroup objects that have similarities with the babies rather than the objects as outgroup objects that do not have similarities with the babies. Babies also prefer the objects with helpful behavior to the objects with bully behavior. However, babies prefer the doll that bullies another doll that is not like the babies. In other words, even though babies dislike the individuals who harm other individuals, babies prefer the individuals who harm outgroup individuals that are not like the babies.

During infancy, the mental protective system and cognition are basic mostly for survival. For the Piaget's cognitive development, infancy and a part of toddlerhood are in the sensorimotor stage $(0-2)$. Infants understand the world through senses and actions. The learned capabilities are the coordination of senses with motor responses and the basic language used for demands and cataloguing. An infant must master the coordination and basic language before moving to the next period.

During infancy, ego development is important because poor parental care can significantly damage the mental immune system. The Erikson's ego crisis during infancy is to trust versus to distrust caregivers. The Erikson's virtue for lifelong capability is the hope to survive in ingroup. Experiencing unhealthy stress when young can cause the child to develop a low stress threshold and become overly reactive to adverse experiences throughout life. The infants without proper care suffer lifelong fear and hopelessness anywhere. Because of the care from the whole group of parents and relatives, human babies have the highest average survival rates of all mammal babies even in the days before modern medicine.

\subsection{Toddlerhood (1.5 - 3)}

- Toddlerhood starts at walking, and the major activity is to explore.

- Collectivistic sociality and territorial worldview

- Regulated hyperactivity against danger and regulated phobia against unfamiliarity-uncertainty

- Committed parents are the protector against danger and the authority against unfamiliarity-uncertainty

- The Erikson's virtue is the will to live in ingroup

Toddlerhood starts at walking which allows toddlers to explore the surrounding and to learn various skills and traditions. Important persons are parents or primary caregivers. Cognitive and linguistic development accelerates around age 2. Sensory areas are myelinated and the motor areas are beginning to myelinate. It is the best time to explore and to learn. Parents and relatives provide a strong base of protection and authority from which the children can venture out to deal with danger and unfamiliarity-uncertainty through learning various skills and various traditions of their ingroup society. Gradually, the learnings and the de- 
velopment of the brain allow toddlers to regulate hyperactivity and phobia. Relentless cry becomes infrequent, and delayed gratification becomes possible.

The Erikson's ego crisis during toddlerhood is to autonomy versus to doubt/shame. Sufficient learned skills and learned traditions allow a toddler to have autonomy. Insufficient learned skills and learned traditions cause a toddler to have doubt/shame. The Erikson's virtue for lifelong capability is the will to live in ingroup.

\subsection{Pre-Juvenile Age (Preschooler 3 - 6)}

- Pre-juvenile age starts at weaning, and the major activity is to initiate.

- Collectivistic sociality, interdependent sociality, and territorial worldview

- Regulated hyperactivity against danger, regulated phobia against unfamiliarity-uncertainty, and unregulated comforter against hardship

- Committed parents are the protector against danger, the authority against unfamiliarity-uncertainty, and the love against hardship

- The Erikson's virtue is the purpose to live in ingroup

Pre-juvenile age starts at weaning at the age of about 3 for the human archaeological population whose weaning was about two to three years earlier than other great apes [18]. The earlier weaning allowed higher numbers of childbirths which made Homo sapiens more successful than other great apes in terms of population [19]. The early weaning also makes pre-juvenile age a difficult period without sufficient maturity and the full maternal care that diverts to a newborn sibling. Other great apes whose weaning occurs at the age of five or six do not have this difficult pre-juvenile age.

Without full maternal care, pre-juvenile is forced to initiate. Without sufficient maturity, pre-juvenile inevitably faces stress from hardship. The instinctive countermeasure against hardship is comforter to maintain durability. A common comforter is imagination companion and/or imaginary self in the imaginary world. Up to two-thirds of children between the ages of 3 and 8 have imaginary companions [20]. Without full maternal care and sufficient maturity, they need imaginary companions to provide comfort in times of stress, boredom, and loneliness, to help them make sense of the adult world, and to overcome traumatic experiences. Taylor feel imaginary companions are common among children and are part of normal social-cognitive development [21]. Without sufficient mental maturity, pre-juveniles have unregulated comforter without delayed gratification.

According to Jean Piaget, pre-juveniles start to use the language with proper syntax and grammar to express full concept. The language with proper syntax and grammar provides the necessary tool to describe, think, and express precisely and accurately complex occurrences such as false beliefs. With the ability to describe, think, and express in the language with proper syntax and grammar, pre-juveniles start to have explicit theory of mind for complex occurrences. Without the language of proper syntax and grammar, human toddlers and other 
great apes have only implicit theory of mind which gets confused easily and explicitly about complex occurrences such as false beliefs [22]. Explicit theory of mind allows pre-juveniles to understand other people's attitudes and specialties and to coordinate with them. After weaning, pre-juveniles still highly depend on older individuals for food and protection until about age 6 or 7 years old. Through explicit theory of mind, pre-juveniles find and coordinate with right older individuals with right attitudes and specialties to help them. As a result, with explicit theory of mind, pre-juveniles without full maternal care could survive after weaning in the hunter-gatherer society during the human evolution, while other great apes without explicit theory of mind needed full maternal care until the age of five or six.

The Erikson's ego crisis during pre-juvenile age is initiative versus frustration in this difficult period. Pre-juveniles minimize frustration by comforter and theory of mind to find the right older individuals to help them. Successful initiative with minimum frustration allows pre-juveniles to find the lifelong purpose as the Erikson's virtue to live in ingroup.

\subsection{Juvenile Age (Schooler 6 - 12)}

- Juvenile age starts at losing the first baby tooth, and the major activity is to accomplish.

- Collectivistic sociality, interdependent sociality, and territorial worldview

- Regulated hyperactivity against danger, regulated phobia against unfamiliarity-uncertainty, and regulated comforter against hardship

- Committed parents are the protector against danger, the authority against unfamiliarity-uncertainty, and the love against hardship

- The Erikson's virtue is the competence to live in ingroup

Juvenile age starts at losing the first baby tooth, and the major activity is to accomplish. Important persons are parents, peers, family, and teachers. Replacing baby teeth with permanent teeth allows juvenile to masticate adult-type foods [23]. Children before juvenile age cannot walk as efficiently as older people [24], so they cannot walk long distance to find foods for themselves in the hunter-gatherer society. With permanent teeth and efficient walk, juveniles as hunters and gatherers can find and eat adult-type foods. In the modern time, juveniles go to school to become schoolers to learn adult tasks. Juvenile age is necessary to grow physically and to participate in adult activity to learn various advanced skills.

By age six, the brain is $95 \%$ its adult weight and peak of energy consumption. The grey matter for neural connections is still pruning, and the white matter with the fatty tissues is increasing to speed up electrical impulses and stabilize connections. Sufficient mental maturity allows juveniles to have regulated comforter with delayed gratification. As juveniles grow older, individualized personal imaginary companions during pre-juvenile age are replaced by shared religious supernatural entities to comfort individuals overcoming hardship. To an 
older juvenile, individualized personal imaginary companion is just a fond memory.

For the Piaget's cognitive development, juvenile age is in the concrete operational [7] [8] [9] [10] [11]. Juveniles understand the world through concrete rational thinking and categories. The learned capabilities are concepts attached to concrete situations. A juvenile must master concepts attached to concrete situations before moving to the next period. The Erikson's ego crisis during juvenile age is industry versus inferiority. Sufficient learning and accomplishment in some adult tasks allow a juvenile to become industry in ingroup. Insufficient learning and accomplishment in adult tasks cause a juvenile to have inferiority. The Erikson's virtue for lifelong capability is the competence to live in ingroup.

\section{Adolescence and Adulthood}

The Erikson's psychosocial development for adulthood has three stages (young adulthood, middle adulthood, and late adulthood), while the psychosocial protective development has six stages for adulthood (young adulthood, late young adulthood, early middle adulthood, late middle adulthood, early late adulthood, and late late adulthood) to show more complex adulthood. The Piaget's cognitive development has one stage, formal operational, for adolescence and early young adulthood. The starts of the six stages of adulthood correspond to the Confucius' six milestones. Confucius said: “At fifteen my heart was set on learning; at thirty I stood firm; at forty I had no more doubts; at fifty I knew the mandate of Heaven; at sixty my ear was obedient; at seventy, I could follow my heart's desire without transgressing the norm." (Analects 2:4) Adolescence and adulthood for the psychosocial protective development, the Erikson's psychosocial (ego-social) development, the cognitive development, and Confucius' (educated person's) six milestones of life are shown in Table 6.

\subsection{Adolescence (12 - 18)}

- Adolescence starts at puberty, and the major activity is to search for identity.

- Collectivistic sociality, interdependent sociality, transition to individualistic sociality, territorial worldview, transition to competitive-connective worldviews

- Regulated hyperactivity against danger, regulated phobia against unfamiliarity-uncertainty, regulated comforter against hardship, and unregulated rationality against unfamiliarity-uncertainty

- The Erikson's virtue is fidelity

- The formal operational stage for cognitive development

Adolescence starts at puberty, and the major activity is to search for identity. Adolescents gradually transit to individualistic sociality and competitive-connective worldviews without boundary. The onset of puberty is the hallmark of the stage of adolescence to bring about various physical, psychological and behavioral changes. Hormones are the driving forces behind these events, with testosterone peaking in males and estrogen rising in females. The hormones and the brain 
Table 6. Adolescence and adulthood.

\begin{tabular}{|c|c|c|c|c|c|c|c|}
\hline age & $12-18$ & $18-25$ & $25-40$ & $40-50$ & $50-70$ & $70-85$ & $85+$ \\
\hline stage & adolescence & $\begin{array}{l}\text { early young } \\
\text { adulthood }\end{array}$ & $\begin{array}{l}\text { late young } \\
\text { adulthood }\end{array}$ & $\begin{array}{l}\text { early middle } \\
\text { adulthood }\end{array}$ & late middle adulthood & early late adulthood & late late adulthood \\
\hline start at & puberty & $\begin{array}{l}\text { higher learning } \\
\text { - childbirth }\end{array}$ & $\begin{array}{c}\text { full } \\
\text { independence }\end{array}$ & $\begin{array}{l}\text { full maturity - } \\
\text { perimenopause }\end{array}$ & menopause & cutback-retirement & declining endurance \\
\hline $\begin{array}{l}\text { Confucius' } \\
\text { milestone }\end{array}$ & & $\begin{array}{c}15 \\
\text { set on higher } \\
\text { learning }\end{array}$ & $\begin{array}{c}30 \\
\text { stand firm }\end{array}$ & $\begin{array}{c}40 \\
\text { no more doubt }\end{array}$ & $\begin{array}{c}50 \\
\text { mandate of heaven }\end{array}$ & $\begin{array}{c}60 \\
\text { deeper level } \\
\text { understanding }\end{array}$ & $\begin{array}{c}70 \\
\text { integration }\end{array}$ \\
\hline $\begin{array}{l}\text { major } \\
\text { activity }\end{array}$ & to search identity & independence & $\begin{array}{l}\text { family and } \\
\text { career }\end{array}$ & $\begin{array}{l}\text { family, career, } \\
\text { and supporting } \\
\text { old parents }\end{array}$ & $\begin{array}{c}\text { active } \\
\text { leadership-mentorship }\end{array}$ & $\begin{array}{c}\text { advisory } \\
\text { leadership-mentorship }\end{array}$ & $\begin{array}{c}\text { wise } \\
\text { leadership-mentorship }\end{array}$ \\
\hline sociality & $\begin{array}{l}\text { collectivistic } \\
\text { interdependent } \\
\text { transition to } \\
\text { individualistic }\end{array}$ & $\begin{array}{l}\text { collectivistic } \\
\text { interdependent } \\
\text { individualistic }\end{array}$ & $\begin{array}{c}\text { collectivistic } \\
\text { interdependent } \\
\text { individualistic }\end{array}$ & $\begin{array}{l}\text { collectivistic } \\
\text { interdependent } \\
\text { individualistic }\end{array}$ & $\begin{array}{c}\text { collectivistic } \\
\text { interdependent } \\
\text { individualistic }\end{array}$ & $\begin{array}{l}\text { collectivistic } \\
\text { interdependent } \\
\text { individualistic }\end{array}$ & $\begin{array}{c}\text { collectivistic } \\
\text { interdependent } \\
\text { individualistic }\end{array}$ \\
\hline generativity & & & & & active & advisory & wise \\
\hline worldview & $\begin{array}{l}\text { territorial transition to } \\
\text { competitive-cooperative }\end{array}$ & $\begin{array}{l}\text { territorial } \\
\text { competitive } \\
\text { cooperative }\end{array}$ & $\begin{array}{l}\text { territorial } \\
\text { competitive } \\
\text { cooperative }\end{array}$ & $\begin{array}{l}\text { territorial } \\
\text { competitive } \\
\text { cooperative }\end{array}$ & $\begin{array}{l}\text { territorial } \\
\text { competitive } \\
\text { cooperative }\end{array}$ & $\begin{array}{l}\text { territorial } \\
\text { competitive } \\
\text { cooperative }\end{array}$ & $\begin{array}{l}\text { territorial } \\
\text { competitive } \\
\text { cooperative }\end{array}$ \\
\hline rationality & unregulated & unregulated & regulated & regulated & regulated & regulated & regulated \\
\hline $\begin{array}{l}\text { Erikson's } \\
\text { stage }\end{array}$ & $\begin{array}{c}12-18 \\
\text { adolescence }\end{array}$ & $\begin{array}{c}18-40 \\
\text { young } \\
\text { adulthood }\end{array}$ & & & $\begin{array}{l}40 \text { - } 65 \\
\text { middle adulthood }\end{array}$ & & $\begin{array}{l}\quad 65+ \\
\text { late adulthood }\end{array}$ \\
\hline $\begin{array}{l}\text { Erikson's } \\
\text { virtue }\end{array}$ & fidelity & love & & & generativity & & wisdom \\
\hline
\end{tabular}

structure during adolescence provide the drive for risk-taking to move out of boundary of family and to find new identity.

According to the Jean Piaget's cognitive development, juvenile in the Piaget's concrete operational stage begins to think in logical structures to explain concrete existence. The rational brain for juveniles starts to form, but rationality does not explain unfamiliarity-uncertainty without concrete existence. On the other hand, rationality for adolescents includes increased abilities to use abstract thought and logic, hypothetical situations or thought, and introspection. Adolescents in the Piaget's formal operation stage start to use rationality as a countermeasure against unfamiliarity-uncertainty for the mental immune system. However, since the rational brain is not fully developed during adolescence, rationality countermeasure is unregulated without delayed gratification. The combination of risk-taking and unregulated rationality generates tumulus adolescence, especially in the parent-child relation. According to Erikson, the psychosocial crisis of identity versus role confusion results from basic identity versus the lack of basic identity. The virtue is fidelity to the basic identity which can be changed later in life. Adolescents usually reach full physical development at about 18 . 


\subsection{Early Young Adulthood (18 - 25)}

- Early young adulthood starts at higher learning-first childbirth, and the major activity is to achieve full independence.

- The Confucius' milestone is to set on higher learning.

- Collectivistic sociality, interdependent sociality, individualistic sociality, territorial worldview, competitive-cooperative worldviews

- The transition between partially independence to fully independence from parents

- Regulated hyperactivity against danger, regulated phobia against unfamiliarity-uncertainty, regulated comforter against hardship, and unregulated rationality against unfamiliarity-uncertainty

- The Erikson's virtue is love.

- The formal operational stage for cognitive development

Early young adulthood starts at higher learning as the Confucius' first milestone; "at fifteen my heart was set on learning". Normally, a person starts to pursuit higher learning such as college education and career at the age of 18 . In the hunter-gatherer society, the average age for the first childbirth is 19. Young adults in twenties until mid to late $30 \mathrm{~s}$ are at the peak of physiological development including reproductive system, motor ability, strength, and lung capacity. After mid to late $30 \mathrm{~s}$, these systems start a slow and gradual decline to show signs of aging.

During the early young adulthood, the brain still is maturing, specifically in the prefrontal cortex for rationality, until at least the mid-20 s. Without completely mature rational brain, early young adults still have unregulated rationality against unfamiliarity-uncertainty, and formal operational stage for cognitive development. The early young adulthood is called emergent adulthood [25], when early young adults are partially independent, and still partially dependent on their parents. The major activity is to achieve full independence. Because of higher learning and forming family, early young adults expose to individualistic sociality outside of collectivistic sociality in childhood family. Individualistic sociality is to protect individuals through reciprocity without commitment. The parents of early young adults start to transform from the commitment to their children to reciprocal relation to their children. In the reciprocal relation, early young adults have to be responsible to their actions. Early young adults move out of childhood family with clear boundary into the society without clear boundary, so territorial worldview with boundary is transformed into competitive-cooperative worldviews without boundary.

For Erikson, the early adulthood (18 - 40) covers early young adulthood, late young adulthood, and early middle adulthood. Under individualistic sociality and competitive-cooperative worldviews without boundary, early young adults face the psychological crisis of intimacy versus isolation with respect to forming family. The virtue is love in terms of forming family. 


\subsection{Late Young Adulthood (25 - 40)}

- Late young adulthood starts at fully independence, and the major activities are family and career.

- The Confucius' milestone is to stand firm.

- Collectivistic sociality, interdependent sociality, individualistic sociality, territorial worldview, competitive-connective worldviews

- Parents as active elder leader-mentor

- The postformal operational stage for cognitive development

- Regulated mental immune system

Late young adulthood starts at fully independent as the Confucius' second milestone, "at thirty I stood firm". The brain at the age of 25 is nearly fully mature, more mature than the brain in adolescence stage and early young adulthood stage. Late young adulthood stage can be described as the postformal operation stage after the Piaget's formal operation stage for adolescence and early young adulthood. Postformal thought in the postformal operation stage is more realistic, flexible, dialectical, tolerated, and complex than formal thought in the formal operation stage [26] [27]. Postformal though is manifested as regulated rationality against unfamiliarity-uncertainty. Regulated rationality avoids unregulated rationality which has overactive rationality against ubiquitous perceived unfamiliarity-uncertainty. Late young adults have completely regulated mental immune system which provides the resistance to chronic mental illness. Half of all chronic mental illness begins by age 14 and three-quarters by age 24 [28] Drug abuse peaks between the ages of 19 and 25 and then begins to decline [29].

The major activity is raising family and pursuing career. According to Levinson, late young adults have an image as "the dream" of the future that motivates them [30] [31]. For men, the dream is about their career paths, while for women, the dream is a "split dream" for both work and family life. The parents of late young adults are in late middle adulthood (age 50 - 70). They are active elder leaders-mentors. The parent-child relation for independent adult child is reciprocal. If parents as elders provide proper and beneficial leadership-mentorship to their independent children, their independent children follow and support their leadership-mentorship. On the other hand, when parents-elders do not provide proper and beneficial leadership-mentorship to their independent adult children, their independent children do not need to follow and support their leadership-mentorship.

\subsection{Early Middle Adulthood (40 - 50)}

- Early middle adulthood starts at full maturity (the maximum brain size)-perimenopause, and the major activities are family, career, and supporting old parents.

- The Confucius' milestone is no more doubt.

- Collectivistic sociality, interdependent sociality, individualistic sociality, competitive-connective worldview with society 
- Regulated mental immune system

Early middle adulthood starts at perimenopause-full maturity (the maximum brain size) as the Confucius' third milestone, "at forty I had no more doubts" for the certainty in understanding. With many years of experiences and full maturity, the certainty in understanding is expressed as tacit knowledge based on "know-how" or "professional instinct." [32]. Some early middle adults become experts in various professions, such as carpenters, chefs, and hair dressers [33].

For women, early middle adulthood also starts at perimenopause with menstrual irregularity as the signs of progression toward menopause. It becomes difficult to conceive. The major activities are raising family, pursuing career, and supporting old parents. Early middle adults often are stressful with too many demands placed on them. Early middle adults as parents adjust to launching their young children into lives of their own as adolescents and early young adults. They as children adjust to helping their old parents into lives of late adulthood. The parent-child relation is reciprocal. For early middle adults, since their parents took care of them when they were young, it is their responsibility to return the favor to their parents when they are older.

\subsection{Late Middle Adulthood (50 - 70)}

- Late middle adulthood starts at menopause, and the major activity is to be active in leadership-mentorship.

- The Confucius' milestone is to know the mandate of Heaven.

- Collectivistic sociality, interdependent sociality, individualistic sociality, territorial worldview, competitive-cooperative worldviews

- Active generativity sociality to protect next generation

- Regulated mental immune system

- The Erikson's virtue is generativity.

Late middle adulthood starts at menopause and leadership-mentorship as the Confucius' fourth milestone, “at fifty, I knew the mandate of Haven”. At fifty, knowing the mandate of Heaven by abundant knowledge, experiences, and social connections, late middle adults start to take the roles of leaders-mentors to guide younger people. At the same time, biologically, women experience menopause at the age of about 50, and become infertile. In the monogamous society, after menopause, the infertile leaders-mentors (monogamous couples) cannot have dependent children, so without dependent children, the reciprocal infertile leaders-mentors are generous in protecting the next generation instead of their own dependent children, resulting in Erikson's generativity. Generativity sociality is a part of the human mental protective system to protect next generation. The Erikson's psychosocial crisis is generativity versus stagnation results from with generativity versus without generativity. Without generativity, life stagnates and ends without future. Generativity essentially is the base for legacy and immortality. The virtue is active mentorship-leadership for generativity.

The generous, knowledgeable, experienced, and well-connected infertile 
leader-mentor to protect the next generation provided a significant evolutionary competitive advantage in the human evolution, resulting in long life after menopause unlike other great apes that have short life after menopause. Increased longevity through generativity was proved by the computer simulation of increased longevity through grandmothering [12]. During the human evolution, some unique variants, such as ApoE3, in genes were evolved to lower the the risk of most aging diseases [13]. Long life can be maintained by moderate diet, continued work and activity, family and community life, and exercise and relaxation [34].

\subsection{Early Late Adulthood (70 - 85)}

- Early late adulthood starts at cutback-retirement, and the major activity is advisory leadership-mentorship.

- The Confucius' milestone is deeper level understanding.

- Collectivistic sociality, interdependent sociality, individualistic sociality, territorial worldview, competitive -connective worldviews

- Advisory generativity sociality to protect next generation

- Regulated mental immune system

At 70, most late middle adults typically fulfill their active mentorship-leadership. For Confucius, "at sixty my ear was obedient" to understand people on a deeper level. Such deep understanding is suitable for advisory leadership-mentorship to replace active mentorship-leadership by cut back or retirement. People now stay healthy longer than Confucius' time, so people start to cut back or retire and take advisory role in leadership-mentorship at the age of 70 instead of 60 . The brain begins declining at $5 \%$ per decade after the age of 40 , speeding up around 70 [15]. Some healthy late adults continue to serve actively after 70. For Americans in 2014, a majority (61 percent) of people ages 55 - 64 were employed compared with 25 percent of those ages 65 - 74 and 8 percent of those age 75 and over [35]. For American early late adults in age group 75 - 84 in the survey from 2013-2014, 76\% were in good health, and $12 \%$ had dementia [35].

\subsection{Late Late Adulthood (85+)}

- Late late adulthood starts at declining endurance, and the major activity wise leadership-mentorship.

- The Confucius' milestone is to integrate all happenings.

- Collectivistic sociality, interdependent sociality, individualistic sociality, territorial worldview, competitive -connective worldviews

- Wise generativity sociality to protect next generation

- Regulated mental immune system

- The Erikson's virtue is wisdom.

According to the Confucius' development, the milestone is described as "at seventy I could follow my heart's desire without overstepping the boundaries of what was right" to integrate all happenings. Such integration is suitable for wise 
leadership-mentorship to establish very broad perspective. People now stay healthy longer, so the milestone is at 85 instead of 70 . Confucius himself lived to the age of 73 . At 85 , most late middle adults start to slow down due to declining endurance. Late late adults start to examine their lives. For Erikson, the psychological crisis is ego integrity for the people who see their lives as productive lives versus despair for the people who see their lives as unproductive lives. Erikson's virtue for this stage is wisdom to reach a closure to integrate all happenings in life. For American late late adults in age group $85+$ in the survey from 2013-2014, 68\% were in good health, and 27\% had dementia [35].

\section{Parent-Child Relation in the Abrahamic Religions and Confucianism}

A most important relation for most people is parent-child relation. The parent-child relation for dependent child during childhood is quite different from the parent-child relation for independent child during adulthood. Under collectivistic sociality to protect children, the role of parent for dependent child during childhood is the commitment to provide protection-authority-love which is essential for the mental immune system of dependent child. The mental immune system of child relies on parent. Dependent child during childhood has highly restricted free will due to highly dependence on parent. Under individualistic sociality to protect individuals, the role of parent as elder for independent adult child during adulthood is the reciprocity mainly to provide leadership-mentorship to independent adult child when independent adult child follows and supports the leadership-mentorship. Adults have to take care of their mental immune system themselves independent of parents. Independent adult child during adulthood has free will.

Human religious experiences are basically derived from human life experiences. The foundation of both the Abrahamic religions (Judaism, Christianity, and Islam) and Confucianism is parent-child relation. Therefore, the foundation of these religions is derived from the human life experiences of parent-child relation. There are three major differences between the Abrahamic religions and Confucianism. Firstly, the Abrahamic religions have much closer and more intimate relation with God than all other religions in the world. In the Abrahamic religions, God is implicitly or explicitly heavenly parent. In a psalm of David, the Lord is my shepherd, I lack nothing. He makes me lie down in green pastures, he leads me beside quiet waters, he refreshes my soul. He guides me along the right paths for his name's sake. Even though I walk through the darkest valley, I will fear no evil, for you are with me; your rod and your staff, they comfort me. (Psalm 23:1-4) In the psalm, the Lord is the protector-authority-love to David. The relation between David and the Lord is essentially heavenly parent-child relation. In Jesus' (Lord's) prayer, God is explicitly our heavenly father. According to Jesus, this, then, is how you should pray: "Our Father in heaven, hallowed be your name." (Matthew 6:9) A believer is the child of heavenly parent. Therefore, 
the foundation of the Abrahamic religions is heavenly parent-child relation to represent God-believer relation.

During Confucius' time, the word for God was Heaven. Confucius did not consider God (Heaven) as heavenly parent with very close committed relation. Heaven was more like the remote and respectful supreme leader-mentor. The remote Heaven-human relation was reciprocal without commitment. In Chinese tradition, the Mandate of Heaven was given only to the rulers who ruled virtuously. Confucius respected Heaven-human relation. Confucius said, "Working to give the people justice and paying respect to the spirits, but keeping away from them, you can call wisdom." (Analects 6:22) Confucius said, "There are three things of which the superior man stands in awe. He stands in awe of the ordinances of Heaven. He stands in awe of great men. He stands in awe of the words of sages." (Analects 16:8) Confucius said, "Filial piety and fraternal respect are the roots of benevolence." (Analects I: 2) Confucius explained extensively filial piety. As a result, the foundation of Confucianism is human parent-child relation instead of heavenly parent-child relation.

The second major difference between the Abrahamic religions and Confucianism is the mental immune system during adulthood. For the mental immune system in the Abrahamic religions, independent children (believers) during adulthood seek protection-authority-love from committed heavenly parent against danger, unfamiliarity-uncertainty, and hardship. Independent children during adulthood also seek leadership-mentorship from reciprocal heavenly parent. On the other hand, for the mental immune system in Confucianism, independent children during adulthood utilize mainly their rationality and experience against danger, unfamiliarity-uncertainty, and hardship without dependence on human parents and myth. In Confucianism, independent children seek mainly leadership-mentorship from their reciprocal parents-elders. The third major difference is that the worldview of the global Abrahamic religions without boundary is competitive, while the worldview of global Confucianism without boundary is cooperative.

In summary, the foundation of the Abrahamic religious and Confucianism is parent-child relation. The three major differences are the foundation (heavenly parent-child relation versus human parent-child relation), the mental immune system (dependence on heavenly parent versus dependence on rationality and experience), and the worldview for global religion without boundary (competitive versus cooperative). On the other hand, they are similar in terms of the emphasis in family value, the respect for cultural tradition, and the idealized idyllic childhood family in supernatural. The comparison between the Abrahamic religions and Confucianism is described in Table 7.

\subsection{The Abrahamic Religions}

- The foundation is heavenly parent-child relation as God-believer relation.

- The mental immune system for independent child (believer) during adulthood 
Table 7. The Abrahamic religions and Confucianism.

\begin{tabular}{|c|c|c|}
\hline & Abrahamic religions & Confucianism \\
\hline foundation & heavenly parent-child relation & human parent-child relation \\
\hline God & committed and reciprocal heavenly parent & reciprocal supreme leader-mentor \\
\hline mental immune & dependence on heavenly parent & dependence on rationality and \\
\hline system & $\begin{array}{l}\text { follow the natural mental immune system } \\
\text { for children }\end{array}$ & $\begin{array}{l}\text { experience follow the natural mental } \\
\text { immune system for adults }\end{array}$ \\
\hline $\begin{array}{l}\text { global religion } \\
\text { without boundary }\end{array}$ & competitive worldview & cooperative worldview \\
\hline supernatural & $\begin{array}{l}\text { idealized idyllic childhood family with } \\
\text { heavenly parent in supernatural }\end{array}$ & $\begin{array}{l}\text { idealized idyllic childhood family in } \\
\text { supernatural }\end{array}$ \\
\hline
\end{tabular}

relies on committed heavenly parent.

- Idealized idyllic childhood experience based on idealized heavenly parent-child relation provides family value, cultural tradition, and idealized idyllic childhood family with heavenly parent in supernatural.

- Under individualistic sociality, reciprocal heavenly parent provides leadership-mentorship to independent child (believer).

- The global Abrahamic religions without boundary have competitive worldview.

In the Abrahamic religions, God is assumed implicitly or explicitly as heavenly parent, and the believers are God's children. In the Abrahamic religions, the mental immune system of adult believers relies on heavenly parent as that the mental immune system of dependent children relies on parents. To dependent child under collectivistic sociality, committed parents are the protector against danger, the authority against unfamiliarity-uncertainty, and the love against hardship. To the adult believers in the Abrahamic religions under collectivistic sociality, heavenly parent provides the protection against danger, the authority against unfamiliarity-uncertainty, and the love against hardship. The heavenly parental protection in the form of miraculous salvation is the religious hyperactivity as the countermeasure against danger. For Judaism, the confirmation for the miraculous salvation is the miraculous salvation of Israelites from oppression and the deliverance into the Promised Land. For Christianity, the confirmation is the miraculous salvation through Jesus' sacrifice and resurrection. For Islam, the confirmation is the miraculous salvation of Mecca to herald the advent of the Prophet Muhammad. The Abrahamic religions celebrate the miraculous salvations every year. The heavenly paternal-like authority in power, laws, and traditions provides the phobia against moving to unfamiliar-uncertain way of life (sins). The authority is expressed as righteousness. For the Abrahamic religions, the heavenly authority (righteousness) is written in the sacred scriptures. The heavenly maternal-like love is the religious comforter as the countermeasure against hardship. For the Abrahamic religions, God is love. Whenever the believers face adversities, the believers seek relentlessly for the heavenly miraculous salvation against danger, the heavenly authority against unfamiliarity-uncertainty, and 
the heavenly love against hardship.

As in the childhood mental immune system, the religious immune system in the Abrahamic religions started with the unregulated immune system without any delayed gratification. The impatient believers want the religious countermeasures at once. There are many stories about such unregulated religious countermeasures in the Abrahamic religions. For examples, in the long journey from Egypt to the Promise Land, Israelites frequently complained, and wanted immediate miraculous salvation without delay as what infants normally do. Inevitably, God taught Israelites to wait for the right time with delayed gratification. God the heavenly parent introduced the heavenly providence (wisdom) as the religious regulator to regulate the religious immune system. The heavenly providence prevents overactive religious countermeasure against ubiquitous perceived adversity as in personality-mental disorders. Believing in the heavenly providence, a believer in the heavenly miraculous salvation looks beyond prevailing danger to the coming of the divine salvation, resulting in the elimination of the overactive religious hyperactivity against ubiquitous perceived danger. Believing in the heavenly providence, a believer in the heavenly authority looks beyond prevailing unfamiliarity-uncertainty (sins) to the coming of the heavenly authority, resulting in the elimination of the overactive religious phobia against ubiquitous perceived unfamiliarity-uncertainty. Believing in the heavenly providence, a believer in the heavenly love looks beyond prevailing hardship to the coming of the heavenly love, resulting in the elimination of the overactive religious comforter against ubiquitous perceived hardship. Essentially, the Abrahamic religions follow the natural regulated immune system for children.

The idealized parent-child relation is the foundation of idealized childhood experience. Childhood is basically idyllic under devoted commitment in collectivistic sociality, existential division of labor in interdependent sociality, protective territorial worldview with definite boundary, and regulated mental immune system. In contrast to idyllic childhood, adulthood is tough under reciprocity in individualistic sociality without devoted commitment, competitive-connective worldviews without protective boundary, and rationality without passion. The idealized childhood experience based on the idealized parent-child relation is the foundation of family value. Family value is based on idealized childhood experience in terms of devoted commitment in collectivistic sociality, existential division of labor in interdependent sociality, protective territorial worldview with definite boundary, and regulated mental immune system. Family value does not emphasize reciprocity in individualistic sociality without devoted commitment, competitive-connective worldviews without protective boundary, and rationality without passion. The idealized childhood experience based on the idealized parent-child relation is also the foundation of cultural tradition. All mental countermeasures except rationality are developed during childhood. Children learn basic skills, knowledge, and cultural tradition during childhood.

The Abrahamic religions want to establish religious organizations based on 
family value and cultural tradition from idealized idyllic childhood. In Christianity, the believers call one another brothers and sisters with God as their heavenly father in the idealized idyllic divine family. The Abrahamic religions assign special supernatural places for the idyllic childhood family. In the Abrahamic religions, childhood is represented by the Garden of Eden, and adulthood is represented by the world outside of the Garden of Eden [36]. The Fall of Adam and Eve represents adolescence. The Garden of Eden represents idyllic and innocent childhood where God is like parent, and Adam and Eve are like God's dependent children. In the Garden of Eden, God as parent provides protection, authority, and love to Adam and Eve as dependent children. During the Fall, like adolescents, Adam and Even question God's protection, authority, and love. They exercise their free will by eating the forbidden fruit from the tree of the knowledge of good and evil to represent the tree of rationality. As a result, rational Adam and Eve move out of the Garden of Eden as idyllic childhood to the outside world as tough adulthood without the direct protection, authority, and love from God as parent. Adam and Eve become independent children to start adulthood. For Christianity and Islam, God's children stay with heavenly parent forever in the supernatural heaven. Jesus is explicit in the supernatural heaven for childhood family. Jesus said, "Let the little children come to me, and do not hinder them, for the kingdom of heaven belongs to such as these." (Matthew 19:14) According to Jesus, there is no marriage in heaven (Matthew 22:30). Heaven is essentially the idealized idyllic childhood family with heavenly parent in supernatural.

Under collectivistic sociality to protect children, the parent-child relation is committed. Under individualistic sociality to protect individuals, the parent-child relation is reciprocal. In Judaism, when Israel and Judah were conquered by the foreign invaders, the believers started to question the commitment of heavenly parent under collectivistic sociality to protect Israelites as God's children. The answer was found in the reciprocal parent-child relation under individualistic sociality. As proclaimed by the prophets during and after the fall of Israel and Judah, when Israelites as independent children failed to follow the leadership-mentorship of heavenly parent, heavenly parent as leader-mentor reciprocally could not provide protection, authority, and love to disobedient Israelites. This reciprocal theology is expressed as Deuteronomist theology which involves the covenant between the Israelites and Yahweh (God), who has chosen the Israelites as his people, and requires Israel to live according to his law [37]. According the vast majority of theologians, the final version of Judaism sacred texts, such as the Pentateuch, was written after the fall of Judah [38] to show the committed and reciprocal heavenly parent. Judaism involves the heavenly parental commitment superimposed by the heavenly parental reciprocity. Christianity and Islam follow Judaism.

After the fall of Judah, the worldview of Judaism was transformed from territorial worldview with national boundary to competitive worldview without na- 
tional boundary. The competition in competitive worldview was zero-sum competition. Only surviving Judaism was the zero-sum competitive Judaism, because the Judaism without zero-sum competition simply disappeared by merging with other cultures. According to archeological evidence [39], before the fall of Judah, idols which was forbidden in Judaism and represented other religions were found commonly in Jewish homes, but after the return from the exile, idols in Jewish homes disappeared to represent zero-sum competition excluding all other religions. Christianity and Islam followed the zero-sum competitive worldview of Judaism. Before the establishment of Christianity as the state religion, many religions coexisted in the Roman Empire. After the establishment of Christianity as the state religion, all other religions and philosophies mostly disappeared. The rise of Islam diminished greatly all other religions. The global Abrahamic religions without boundary have competitive worldview. The extreme zero-sum competitive religions are incompatible to pluralistic politics.

\subsection{Confucianism}

- The foundation is human parent-child relation.

- The mental immune system for independent child during adulthood relies on rationality and experience.

- Idealized idyllic childhood experience based on idealized human parent-child relation provides family value, cultural tradition, and idealized idyllic childhood family in supernatural.

- Under individualistic sociality, reciprocal parent provides leadership-mentorship to independent child. The reciprocal independent child provides care and respect to old parent.

- Global Confucianism without boundary has cooperative worldview.

The foundation of Confucianism is human parent-child relation instead of heavenly parent-child relation. Confucianism does not rely on Heaven for the mental immune system. In Confucianism, the mental immune system for adult believers relies on rationality and experience instead of parent and myth. Rationality from the prefrontal cortex is not well-developed during childhood and adolescence, and rationality is well-developed in adulthood. Confucianism allows the natural countermeasures (hyperactivity, phobia, comforter, and rationality) against adversities to occur naturally. Rationality is used to assist the natural regulators to regulate the mental immune system. One way to utilize rationality is rational balance to regulate the mental immune system. Classic Chinese philosophy is basically about rational balance such as rational balance between yin and yang to keep harmony [40]. A most important rational balance is balanced adversity-fortune to reach harmony. Whenever one thinks too much about adversity, think about possible fortune after adversity. Equally, whenever one thinks too much about fortune, thinks about possible adversity after fortune. Rational balance encourages the middle (mean), and discourages the extreme. Another way to utilize rationality is rational acceptance of the unknown to regu- 
late rationality countermeasure against unfamiliarity-uncertainty. Confucius said:" ... Recognizing that you know what you know, and recognizing that you do not know what you do not know-this is knowledge." (Analects 2:17) Harmony is reached through rationality. The experiences from rationality can be used for the future regulation of the mental immune system. The first chapter of the Book of Mean from Confucianism describes how to deal with emotion, "When joy, anger, sorrow and pleasure have not yet arisen, it is the state of equilibrium. When they arise to their appropriate levels, it is the state of harmony. The state of equilibrium is the great base of of all-under heaven. The state of harmony is the universal path to be pursued. When the states of equilibrium and harmony are actualized, Heaven and Earth are in their proper positions, and all things are nourished." The goals of the regulated mental immune systems are to be in the states of equilibrium (idle regulated mental immune system) without arising emotion (countermeasures), and in the state of harmony (active regulated mental immune system) with arising emotion (countermeasures). Essentially, Confucianism follows the natural regulated mental immune system for adults.

The human parent-child relation for independent adult child is reciprocal. Human parent is extended to elder siblings, elders and ancestors. If parents as elders provide proper and beneficial leadership-mentorship to their independent children, their independent children follow and support their leadership-mentorship. On the other hand, when parents-elders do not provide proper and beneficial leadership-mentorship to their independent adult children, their independent children do not need to follow and support their leadership-mentorship. In Confucianism, another reciprocal relation between parent and child appears when parent become old and weak. For independent adult children, since their parents took care of them when they were young, it is their responsibility to return the favor to their parents when they are older. To Confucius, the three years of mourning after the death of parent was to return the favor for the three years of parental care to a child before weaning (Analects 17:19). Confucius said, "Filial piety and fraternal respect are the roots of benevolence." (Analects I: 2)

As in the Abrahamic religions, in Confucianism, idealized idyllic childhood experience based on idealized human parent-child relation provides the emphasis in family value, the respect for cultural tradition, and idealized idyllic childhood family in supernatural. To Confucius, even laws must respect family value. The Duke of Sheh told Confucius: "In my land, there are righteous men. If a father steals a sheep, the son will testify against him." Confucius said, "The righteous men in my land are different from this. The father conceals the wrongs of his son, and the son conceals the wrongs of his father. This is the correct way!" (Analects 13:18) Confucian culture idealizes family and hometown which are important in the literatures in Confucian culture. In the Confucian tradition, afterlife is the supernatural extension of idealized idyllic childhood family life. Ancestral tablets for ancestors are placed in traditional Confucian homes. For- 
mal rituals are performed in front of ancestral tablets on specific dates and occasions. Such rituals provide a sense of immortality. In the Hofstede's five dimensions (power distance, uncertainty avoidance, individualism/collectivism, masculinity/femininity and long-term orientation) to represent differences among national cultures [41], the culture under Confucianism has extremely and uniquely strong long-term orientation based on the strong human parent-child relation that is extended to many generations.

Confucius lived in the period with continuous wars among the strong local powers, so boundary was not clear. As a result, Confucianism is a global religion without boundary. The worldview is cooperative worldview. Cooperative worldview is expressed as harmony. In Confucianism, "In practicing the rules of propriety, it is harmony that is prized." (Analects 1:12) Harmony is prized among the differences. Confucius said: "Noble persons seek harmony but not sameness. Petty persons seek sameness but not harmony." (Analects 13:23) Under harmonious cooperative worldview, Confucianism, Daoism, and Buddhism are commonly practiced together in harmony. Cooperative religions consider zero-sum competitive worldview as the source of chaos and destruction. Under zero-sum competitive worldview, Judaism, Christianity, and Islam exclude one another. Competitive religions consider harmonious cooperative worldview as the source of impurity and conformity. In the highly globalized and interdependent world today, the believers more likely no longer impose their beliefs on other people in this life and in afterlife.

\section{Summary and Conclusion}

In summary, the proposed eight stages of psychosocial protective development are derived from the mental protective system in the brain and social interactions. Different parts in the mental protective system in the brain emerge and mature in different stages under different social interactions. The formation of the eight stages is derived from the human evolution, and explains the Piaget's cognitive development, the Erikson's psychosocial development, and the Confucius' six milestones of life. As described in the previous paper, the mental protection system consists of the four socialities, the three worldviews, and the mental immune system for the four countermeasures against adversities. The four socialities to protect social members are collectivistic sociality from kin-friends to protect vulnerable children through commitment, individualistic sociality from allies to protect vulnerable individuals through reciprocity, interdependent sociality from interdependent specialists to protect vulnerable pregnant females through interdependent division of labor, and generativity sociality from older leaders-mentors to protect next generation through reciprocity. The three worldviews to protect social functions are territorial worldview with boundary to protect territory through the division of ingroup and outgroup, competitive worldview without boundary to protect competition function, cooperative worldview without boundary to protect cooperation function. The 
mental immune system produces four countermeasures against adversities. An unregulated countermeasure contains no regulator to constrain countermeasure, while a regulated countermeasure contains a regulator to constrain countermeasure. The countermeasures against adversities include hyperactivity against danger to maintain existence, phobia against unfamiliarity-uncertainty to maintain tradition, comforter against hardship to maintain durability, and rationality against unfamiliarity-uncertainty to maintain adaptability.

The proposed eight stages of psychosocial protective system based on the mental protective system and social system for the maturation process are childhood (from birth to 12-year-old), adolescence (12 - 18), early young adulthood (18 - 25), late young adulthood (25 - 40), early middle adulthood (40 - 50), late middle adulthood (50 - 70), early late adulthood (70 - 85), and late late adulthood $(85+)$. The four periods in childhood are infancy (from birth to 1.5-year old), toddlerhood (1.5 - 3), pre-juvenile age (3 - 6), and juvenile age (6 12). During childhood, dependent children have collectivistic sociality under the protection of committed parents and territorial worldview with the boundary of family. Infants without delayed gratification have unregulated hyperactivity and phobia. Toddlers with increasing delayed gratification have regulated hyperactivity and phobia. Pre-juveniles start to initiate, so they need comforters as imaginary companions to overcome hardship. Interdependent sociality starts in pre-juvenile age. Juveniles with delayed gratification have regulated comforter. Adolescents with unregulated rationality transit to individualistic sociality and competitive-cooperative worldviews. Independent adults with the regulated metal immune system have individualistic sociality from allies through reciprocity and competitive-cooperative worldviews without clear boundary. After the age of 50, older people as elder leaders-mentors develop generativity sociality to protect next generation through reciprocity.

The parent-child relation in the psychosocial protective development explains the Abrahamic religions (Judaism, Christianity, and Islam) and Confucianism which are based on parent-child relation. They are different in foundation (heavenly parent (God)-child relation versus human parent-child relation), the mental immune system (dependence on heavenly parent versus dependence on rationality and experience), and worldview (competitive versus cooperative). Essentially, the Abrahamic religions follow the natural regulated immune system for children, while Confucianism follows the natural regulated immune system for adults. The Abrahamic religions undergo zero-sum competition to exclude one another. Confucianism coexists and practices with other religions. They are similar in terms of the emphasis in family value, the respect for cultural tradition, and the idealized idyllic childhood family in supernatural.

In conclusion, the universal psychological mechanism for developmental psychology is the mental protective system whose different parts emerge and mature in the eight different stages of psychosocial protective development under different social interactions. The mental protective system as the universal 
psychological mechanism for developmental psychology explains clearly psychosocial protective development, the human evolution, the Piaget's cognitive development, the Erikson's psychosocial (ego-social) development, the Confucius' (educated person's) six milestones of life, and parent-child relation in the Abrahamic religions and Confucianism .

\section{References}

[1] Hogan, J. and Vaccaro, T (2006) Internationalizing the History of Developmental Psychology. New York University Press, New York.

[2] Wadsworth, B. (2004) Piaget's Theory of Cognitive and Affective Development: Foundations of Constructivism. Longman Publishing, London.

[3] Erikson, E. and Erikson, J. (1998) The Life Cycle Completed. W. W. Norton \& Company, New York.

[4] Erikson, E. (1964) Insight and Responsibility. W. W. Norton \& Company, New York.

[5] Chung, D. (2018) The Mental Protection System for Protective Behaviors: The Social Brain and the Mental Immune System. Journal of Behavioral and Brain Science, 8, 31-55. https://doi.org/10.4236/jbbs.2018.81003

[6] Crespi, B. and Douglas, Y. (1995) The Definition of Eusociality. Behavior Ecology6, 109-115. https://doi.org/10.1093/beheco/6.1.109

[7] Wilson, E.O. (2012) The Social Conquest of the Earth. W. W. Norton \& Company. New York.

[8] Chung, D. (2016) The Basic Principles of Kin Sociality and Eusociality: Human Evolution. Natural Science, 8, 8-19. https://doi.org/10.4236/ns.2016.81002

[9] Fonagy, P., Gergely, G., Jurist, E. and Target, M. (2002) Affect Regulation, Mentalization and the Development of the Self. Other Press, New York

[10] Slater, C.L. (2003) Generativity versus Stagnation: An Elaboration of Erikson's Adult Stage of Human Development. Journal of Adult Development, 10, 53-65. https://doi.org/10.1023/A:1020790820868

[11] McAdams, D. and De St. Aubin, E. (1992) A Theory of Generativity and Its Assessment through Self-Report, Behavioral Acts, and Narrative Themes in Autobiography. Journal of Personality and Social Psychology, 62, 1003-1015. https://doi.org/10.1037/0022-3514.62.6.1003

[12] Kim, P., Coxworth, J. and Hawkes, K. (2012) Increased Longevity Evolves from Grandmothering. Proceedings of the Royal Society B: Biological Sciences, 279, 4880-4884. https://doi.org/10.1098/rspb.2012.1751

[13] Finch, C. and Stanford, C. (2004) Meat-Adaptive Genes and the Evolution of Slower Aging in Humans. The Quarterly Review of Biology, 79, 3-50. https://doi.org/10.1086/381662

[14] Rutter, M. (1981) Stress, Coping and Development: Some Issues and Some Questions. Journal of Child Psychology and Psychiatry, 22, 323-356. https://doi.org/10.1111/j.1469-7610.1981.tb00560.x

[15] Peters, R. (2006) Ageing and the Brain. Postgraduate Medical Journal, 82, 84-88. https://doi.org/10.1136/pgmj.2005.036665

[16] Turner, J. and Reynolds, K. (2010) The Story of Social Identity. In: Postmes, T. and Branscombe, N., Eds., Rediscovering Social Identity: Core Sources, Psychology Press, New York, 13-32. 
[17] Hamlin, J.K., Mahajan, N. and Wynn, K. (2013) Not Like Me = Bad Infants Prefer Those Who Harm Dissimilar Others. Psychological Science, 24, 589-594. https://doi.org/10.1177/0956797612457785

[18] Tsutaya, T. and Yoneda, M. (2013) Quantitative Reconstruction of Weaning Ages in Archaeological Human Populations Using Bone Collagen Nitrogen Isotope Ratios and Approximate Bayesian Computation. PLoS ONE, 8, e72327.

https://doi.org/10.1371/journal.pone.0072327

[19] Bogin, B. and Varea, C. (2016) Evolution of Human Life History. Evolution of Nervous Systems. In: Kaas, J., Ed., Evolution of Nervous Systems, Elsevier, Amsterdam, 37-50.

[20] Taylor, M. (1999) Imaginary Companions and the Children Who Create Them. Oxford University Press, New York.

[21] Taylor, M., et al. (2004) The Characteristics and Correlates of Fantasy in School-Age Children: Imaginary Companions, Impersonation, and Social Understanding. Developmental Psychology, 40, 1173-1187. https://doi.org/10.1037/0012-1649.40.6.1173

[22] Krupenye, C., et al. (2016) Great Apes Anticipate That Other Individuals Will Act According to False Beliefs. Science, 354, 110-114. https://doi.org/10.1126/science.aaf8110

[23] Holly Smith, B., Crummett, T. and Brandt, K. (1994) Ages of Eruption of Primate Teeth: A Compendium for Aging Individuals and Comparing Life Histories. American Journal of Physical Anthropology, 37, 177-231.

https://doi.org/10.1002/ajpa.1330370608

[24] Kramer, P. (1998) The Costs of Human Locomotion: Maternal Investment in Child Transport. American Journal of Physical Anthropology, 107, 71-85. https://doi.org/10.1002/(SICI)1096-8644(199809)107:1<71::AID-AJPA6>3.0.CO;2-G

[25] Arnett, J. (2004) Emerging Adulthood: The Winding Road from the Late Teens though the Twenties. Oxford University, New York.

[26] Basseches, M. (1984) Dialectical Thinking and Adult Development. Ablex Publishing, Norwood, NJ.

[27] Berger, K. (2014) Invitation to the Life Span. Worth Publishers, New York.

[28] Kessler, R., et al. (2005) Prevalence, Severity, and Comorbidity of 12-Month DSM-IV Disorders in the National Comorbitity Survey Replication. Archives of General Psychiatry, 62, 593-602.

[29] Berk, L. (2007) Development through the Lifespan. Allyn and Bacon, Boston. https://doi.org/10.1001/archpsyc.62.6.593

[30] Levinson, D. (1978) Seasons of a Man's Life. Random House, New York.

[31] Levinson, D. (1996) Seasons of a Woman's Life. Alfred A. Knopf, New York.

[32] Hedlund, J., Antonakis, J. and Sternberg, R. (2002) Tacit Knowledge and Practical Intelligence: Understanding the Lessons of Experience. (ARI Research Note 2003-04). U.S. Army Research Institute for the Behavioral and Social Sciences, Arlington, Virginia. https://doi.org/10.21236/ADA412016

[33] Rose, M. (2014) The Mind at Work: Valuing the Intelligence of the American Worker. Penguin Books, London.

[34] Berger, K. (2005) The Developing Person through the Life Span. Worth Publishers, New York.

[35] Federal Interagency Forum on Aging-Related Statistics (2016) Older Americans 2016: Key Indicators of Well-Being. Federal Interagency Forum on Aging-Related 
Statistics. U.S. Government Printing Office, Washington, DC.

[36] Zhitnik, A. (2014) Eden and Erikson: Psychosocial Theory and the Garden of Eden. Journal of Pedagogy, Pluralism and Practice, 6, Article 10.

[37] Brueggemann, W. (2002) Reverberations of Faith: A Theological Handbook of Old Testament themes. Westminster John Knox Press, Louisville, KY.

[38] Ska, J. (2006) Introduction to Reading the Pentateuch. Eisenbrauns, University Park, PA.

[39] Stern, E. (2001) Archaeology of the Land of the Bible, Volume II The Assvrian. Doubleday, New York.

[40] Komjathy, L. (2014) Daoism: A Guide for the Perplexed. Bloomsbury Academic, New York

[41] Hofstede, G. (1997) Cultures and Organizations: Software of the Mind. McGraw-Hill, London. 